\title{
Building the Foundations of Collaboration: From Housing Development to Community Renewal
}

\author{
Zohreh Karaminejad*, Suzanne Vallance, Roy Montgomery \\ Department of Environmental Management, Lincoln University, Lincoln, New Zealand \\ Email: `Zohreh.Karaminejad@lincolnuni.ac.nz, Suzanne.Vallance@lincoln.ac.nz, Roy.Montgomery@lincoln.ac.nz
}

How to cite this paper: Karaminejad, Z., Vallance, S., \& Montgomery, R. (2020). Building the Foundations of Collaboration: From Housing Development to Community Renewal. Current Urban Studies, 8, 599-622. https://doi.org/10.4236/cus.2020.84033

Received: November 16, 2020

Accepted: December 14, 2020

Published: December 17, 2020

Copyright $\odot 2020$ by author(s) and Scientific Research Publishing Inc. This work is licensed under the Creative Commons Attribution International License (CC BY 4.0).

http://creativecommons.org/licenses/by/4.0/

(c) (i) Open Access

\begin{abstract}
While collaborative governance and planning are seen as an improvement on technocratic "top-down" approaches, they are often criticized for exacerbating power imbalances, failing to be inclusive and/or impartial, and for ignoring historical conflict. This paper aims to investigate how strong foundations for collaborative housing renewal may be built so as to facilitate broader community renewal ambitions. Using qualitative methods and based on two case studies of housing renewal projects in communities described as "deprived", we found the informal but foundational phase was critical in mitigating contextual and historical factors that had often led to marginalization during more formal negotiations. The foundations for the housing renewal work involved building trust and credibility, collective community capability, a "grounded" agenda and a mandate. We argue that these foundations should not be seen as informal and therefore optional; rather they fundamentally shape formal processes of collaboration and can be used to address tensions between participative and representative democracy.
\end{abstract}

\section{Keywords}

Collaborative Governance, Collaborative Planning, Housing Renewal

\section{Introduction}

Over the past few decades, collaborative governance and planning have attracted the attention of many scholars from multiple disciplines, including environmental studies (Brisbois, 2015; Koontz \& Newig, 2014; Memon, Duncan, \& Spicer, 2012), political science (Ansell \& Gash, 2008; Dryzek, 1994), public administration (Emerson \& Nabatchi, 2015; Emerson, Nabatchi, \& Balogh, 2012; O'Leary \& Bingham, 2007), public management (Leach, 2006), and planning (Booher, 2004; Forester, 1999; Healey, 1997; Innes \& Booher, 2010; Healey, 2010; 
McCarthy, 2016). This interest reflects a change from the traditional notion of "government", which refers to the top-down, state-led model of decision-making and planning, to multi-stakeholder processes in which non-state actors are more actively involved in discursive and deliberative processes aimed towards consensus-building and conflict-resolution (Brisbois, 2015; Kapucu \& Garayev, 2011; Ansell \& Gash, 2008; Lane, 2005; Laurian \& Shaw, 2008; Booher, 2004; Innes \& Booher, 2010; McCarthy, 2016; Purbani, 2017).

Yet, when the merits and drawbacks of collaboration are evaluated, advocates and critics often adopt quite restrictive definitions focusing on the formal stage of specific projects and programmes where an official agency takes the lead on assembling key stakeholders for a fairly well-prescribed process of negotiation, often in conventional settings such as the meeting rooms at city hall or council chambers. Both abstracted descriptions and evaluations of specific instances are often assessed against Habermasian-derived criteria for ideal speech, such as inclusiveness, impartiality, transparency, and equal power sharing (Roy, 2015; Leach, 2006; Papadopoulos, 2012; Agger \& Löfgren, 2008; Booher, 2004; Brisbois, 2015; Habermas, 1984).

We would argue that the settings and situations within which collaboration is practiced are somewhat at odds with these abstract criteria, as there are many analyses of projects whose evaluation focuses solely on the well-documented (i.e. "minuted" or reported on) aspects of the process. Instead, we take a broader view of collaboration by attending to the less well-recognized and often informal beginnings. While there is reasonable agreement that the context and history are important, less research has systematically and practically analyzed how and why they should be accommodated and interrogated the role they play in success or failure of subsequent, more formal, phases of collaboration. This is a gap in our understanding of collaboration that may apply to any multi-stakeholder decision-making process; however, in our investigation we focus on "communities" as distinct from other sectorial actors. In exploring these ideas, we undertook research into two projects that were widely regarded as "successful" examples of collaborative housing renewal.

\section{Literature Review}

Much of the current scholarship on collaborative governance adopts Ansell and Gash's (2008) definition as an "arrangement where one or more public agencies directly engage non-state stakeholders in a decision-making process that is formal, consensus-oriented and deliberative and that aims to make or implement public policy or manage public programs or assets" (544). The authors recognize that this is a fairly restrictive definition, adopted in part to facilitate their comparative analysis. Nonetheless, their widely cited definition does establish certain parameters that have come to frame and therefore constrain certain areas of debate. In particular, many studies emphasize ways in which "formal" aspects of the process focus on a single but important issue (Buanes, Jentoft, Karlsen, Maurs- 
tad, \& Søreng; 2004; Rogers, Howard-Pitney, Feighery, Altman, Endres, \& Roeseler, 1993; Ansell \& Gash, 2008) such as water quality, transport or housing (Czischke, Carriou, \& Lang, 2020; Szemző, Gerőházi, Droste, \& Soetanto, 2019).

However, what might be considered a public affair is incredibly problematic (Whatmore \& Landström, 2011; Dantec \& DiSalvo, 2013; Buanes et al., 2004; Jiménez, 2014; Vallance, Dupuis, Thorns, \& Edwards, 2017; Lewandowsky, Mann, Brown, \& Friedman, 2016) because key concerns identified by elected members and officials are not always those that residents and communities would like to address, or would like to address as a priority. As Cowie (2017: p. 401) has noted, officials' attempts to place parameters around issue definition can lead to the "dreaded 'community consultation' process [which can open] a gulf between a community's enthusiasm and creativity on the one hand and the strictures of the statutory planning process on the other".

Other issues arise when collaboration is triggered by invitations from decision-makers to communities to begin their deliberations in formal settings (offices or meeting rooms at city hall) documented through formal processes (such as minutes, appointed Chairs, Terms of Reference). Further, given that public agencies are inviting and engaging non-state actors, they generally take a leadership role (Ansell \& Gash, 2008; Bortel \& Gruisy, 2019; Brisboise, 2015; Koontz \& Newig, 2014). Interestingly, this thoroughly orthodox style of collaboration rarely occurs in the place the process is destined to shape, thus the formal context of deliberations privileges distinct forms of problem representation.

As invitations to collaborate are issued and negotiations begin, officials and stakeholders from well-established groups may already have a mandate, considerable experience, information and a wealth of other resources. In contrast, "communities" or "the public" might be little more than a set of diffuse actors or collection of disparate individuals who have never met each other. Consequently, they may not have the ability to participate in deliberative processes on equal terms. According to Purdy (2012), there are three main sources of power in collaborations including resources (tangible such as money and intangible such as educations), authority, and discursive democracy. Local communities typically are less equipped and have less power, so they can be easily co-opted by more powerful actors who try to sway their opinions. This is a critical point because, as Ansell and Gash (2008: p. 551) note "If some stakeholders do not have the capacity, organization, status, or resources to participate, or to participate on an equal footing with other stakeholders, the collaborative governance process will be prone to manipulation by stronger actors".

This raises some very interesting questions about the extent to which orthodox approaches might address concerns about inclusiveness, equity, impartiality, power sharing and conflict resolution (Innes \& Booher, 1999, 2003, 2010; Hillier, 2003; Leach, 2006; Memon, Duncan, \& Spicer, 2012; Mouffe, 2000; Ansell \& Gash, 2008; Roy, 2015). Consequently, we suggest there is a need to be more attentive to alternative ways of working with communities that might provide a 
more solid foundation for collaboration, particularly in cases marked by a history of conflict, distrust and marginalization. Some scholars clearly acknowledge that collaboration often has a history of antagonism, conflict and distrust between the actors (e.g. Andranovich, 1995; Gray, 1989; Gunton \& Day, 2003; Margerum, 2002; Ansell \& Gash, 2008; Emerson \& Nabatchi, 2015; Emerson, Nabatchi, \& Balogh, 2012; O'Flynn \& Wanna, 2008; Warner, 2006). This is not just a cursory point of interest; rather, it clearly influences who is likely to become involved in the process, their roles and influence, and the relationships that are likely to develop between actors. This is particularly the case where conflict and distrust have already become apparent as a result of former top-down plans, marginalization and community exclusion. Some view a history of conflict as a hindrance precluding or limiting the possibilities of collaboration (Gray, 1989; Margerum, 2002; Ansell \& Gash, 2008; Andranovich, 1995) or contribute to power imbalance during deliberations (Ansell \& Gash 2008; Emerson, Nabatchi, \& Balogh, 2012). Conversely, others believe these challenges may help create a stronger motivation to work together (Weber, 2003; Futrell, 2003; Ansell \& Gash, 2008).

In summary, whether a hindrance to be overcome or an opportunity to mobilize, unanswered questions remain around the ways in which the historical context shapes collaboration. Consequently, we raise the possibility of re-writing history and using an informal "pre-collaboration" phase to address a range of issues before, rather than during, formal negotiations. To explore these possibilities, we drew upon case study research concerning two housing renewal projects, one in Aranui (New Zealand) and the other in Abouzar (Iran). These had 1) been lauded as "collaborative" based on community involvement in a formal housing project; 2) a history of conflict, marginalization and distrust and 3) sought to somehow connect housing renewal with better community outcomes. In presenting our results and discussion below, we draw an analogy between the physical form of housing and the need for strong foundations to interrogate the socio-political equivalent: In other words, what groundwork should be done to promote positive community outcomes from collaborative housing renewal projects.

\section{Research Methods and Cases}

This study adopted qualitative research methods and a case study approach in order to adequately accommodate the context of these collaborative housing renewal projects. Qualitative methods were deemed most appropriate because the questions demanded an exploration of subtle nuances in attitudes to examine social process over time (Babbie, 2016; Creswell \& Creswell, 2017). A case study approach involves achieving an in-depth understanding of the setting with individuals, organizations and groups over time, and allows a better appreciation the web of relations and diverse activities in its context (Yin, 2009; Neuman, 2011). While case studies do have limitations, Flyvbjerg (2001) uses the term "power of example" to illustrate the utility of this method in generating concrete, practical 
and context-dependent knowledge.

Our choice of two case studies helped us to identify factors in common and those unique to each case, thus highlighting our theoretical contributions. The two case studies included a social housing renewal project in Christchurch, New Zealand (NZ) and a local authority renewal project in Tehran, Iran. The first case was considered the main case and was used primarily to develop certain themes and ideas. These were tested in the Tehran setting. Case selection was based on certain criteria: First, and most importantly, the examples of housing renewal were associated with claims by officials that although the projects were state-led, they were also collaborative with high levels of community involvement. Second, both Aranui and Abouzar had a history of conflict, marginalization, deprivation and distrust of officialdom. Third, these projects both sought to connect housing renewal with better community outcomes. Finally, the projects had already been implemented which allowed retrospective evaluation of process.

Twenty-eight in-depth, semi-structured interviews were conducted with representatives of public agencies, the communities, developers and others involved in the project over a period of 6 months. In Christchurch (NZ), three planners as Christchurch City Council (CCC) representatives, three Housing New Zealand Corporation (HNZC) managers as representatives of central government, East Christchurch Minister of Parliament (MP), an adult educator from the Ministry of Education, five community representatives and a private developer were interviewed. In Abouzar, five planners and managers as Urban Renewal Organization (URO) representatives, five community representatives and local landowners, two representatives of other council departments (including the district council mayor and the head of council Department of Architecture and Urban Design (DAUD)), two private developers were conducted. We used purposive sampling to choose the first interviewees and then snowball sampling thereafter. Interviews were semi-structured, transcribed and analyzed thematically. The interviews would usually include questions about the participants' memories of the project, how it started, why, who was involved at what points, and so on. The second source of data comprised relevant documents including reports such as Aranui's first scoping plan, surveys like the Needs Analysis, photos, brochures, monthly community newsletters, census data, city council data and reports, media releases, URO monthly reports of Abouzar renewal progress, and correspondence and meeting notes.

\subsection{Case Study One: Aranui Housing Renewal Project (Christchurch, New Zealand)}

Aranui is located in the eastern suburbs of Christchurch, New Zealand (Figure 1 ), and is represented in socio-economic data as "deprived" with low employment, education and income statistics. Aranui is home for different ethnicities including European, Maori ${ }^{1}$, Pacifica and Asian. The main ethnicity living in

${ }^{1}$ Maori are New Zealand indigenous people. 
Aranui is European (69\%) but the population of Maori in Aranui (20\%) is significantly higher than their population in Christchurch city for example (7\%) (Statistics New Zealand, 2001). Aranui is represented at central government level by the Minister for Christchurch East and, at local government level, by a councilor and two community board members.

Aranui was predominantly a rural area until the first half of $20^{\text {th }}$ century when it became a part of Christchurch city (Montgomery, 2016). Subsequently, in the 1950 s and 1960s, a large number of state houses were designed and built in the area, largely through the (then) orthodox welfare state model characterized as "top-down". Later attempts to reduce building costs resulted in the introduction of new designs that included multi-unit buildings, duplexes and non-detached houses (shown in Figure 2) (Boyd, 2011). In the New Zealand context, such

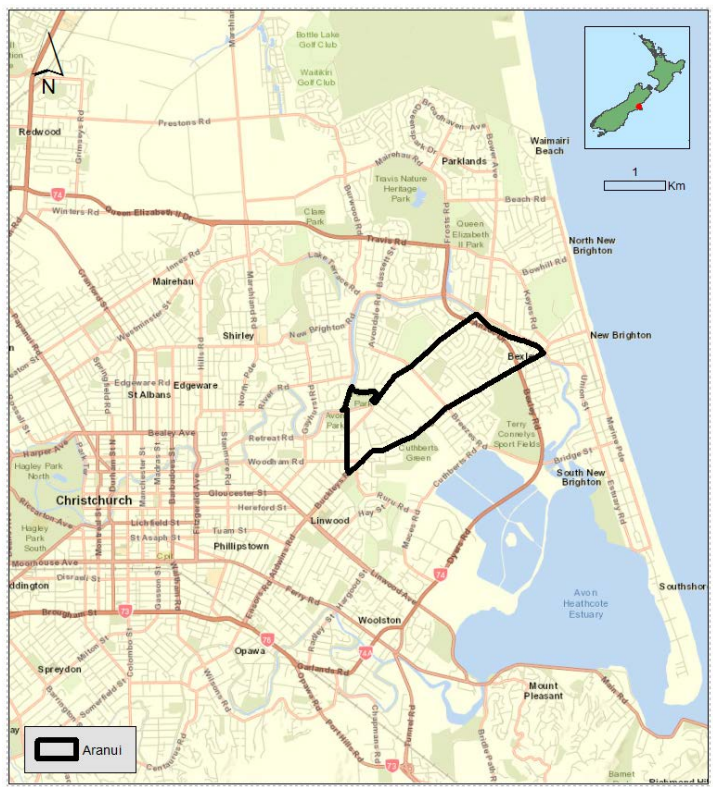

Figure 1. A map showing Aranui as a coastal suburb of Christchurch.

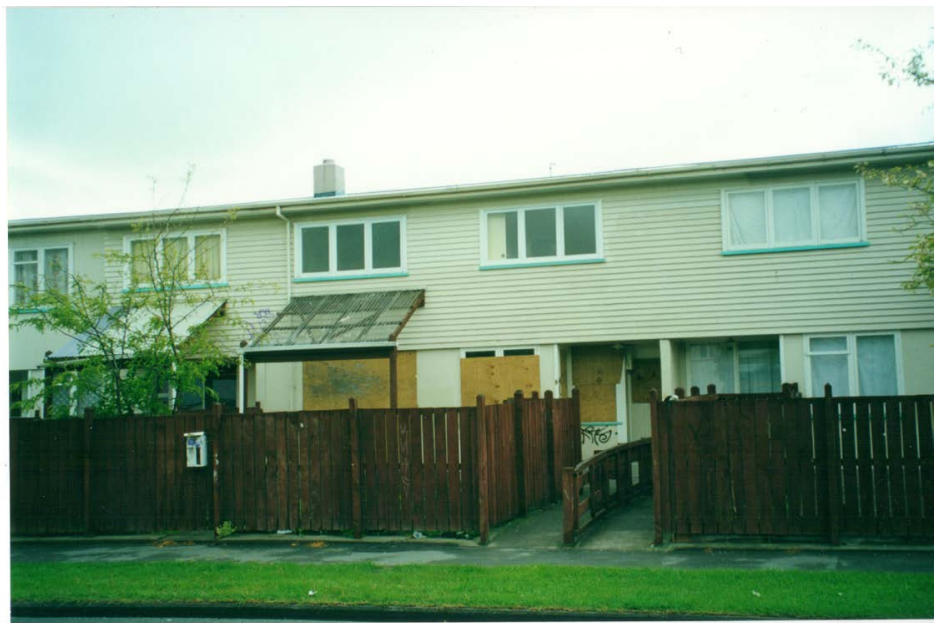

Figure 2. A photo showing a multi-story building in Aranui. 
housing was anomalous because the "ideal" house was, and still is, the detached single dwelling with a garden (Schrader, 2005). The multi-unit buildings caused widespread dissatisfaction because of the lack of privacy and limited private outdoor spaces. They were monotonous and the proximity of several multi-unit buildings promoted territorial gang wars and created safety issues for other residents (Montgomery, 2016). By the 1990s, Aranui had the highest rates of transient population in the city and was over-represented in violent crime statistics (Statistics New Zealand, 2001).

In 1999, New Zealand's newly elected Labor government initiated a program of "housing renewal" projects to be implemented in different neighborhoods across New Zealand that had a high percentage of state houses and a history of social problems. Aranui was chosen as a pilot project that aimed "To foster strong communities in areas of predominantly state houses and to exhibit a sense of social responsibility by having regard to the interests of the communities in which it operates" (HNZC, 2000: p. 4). Critically, soon after the project's inception, senior managers at HNZC (the main central government organization responsible for managing state houses in New Zealand) started to understand that "housing" was just one of many issues, residents were facing. In taking a more holistic approach, HNZC started involving other agencies such as the Christchurch City Council (CCC) and residents from Aranui. Our research, detailed in the results below, focused on the ways in which this collaborative process evolved over time.

\subsection{Case Study Two: Abouzar Housing Renewal Project (Tehran, Iran)}

Abouzar is a neighborhood in the south of Tehran (Figure 3 illustrates Abouzar which is located in 17 District of Tehran) and, again, is considered to be of low socio-economic status. Until the 1940s, the area was largely rural but agricultural land reforms drove urban migration to Tehran and newly urbanized areas like Abouzar (Rasoolimanesh, Jaafar, \& Badarulzaman, 2013). Construction in southern parts of the city were largely undertaken without professional monitoring, often using unstable materials and structures, with very narrow streets and small sections/lots of 45, 50 or $60 \mathrm{~m}^{2}$ (Figure 4 shows one of these streets in Abouzar). These areas were poorly serviced and often overlooked in the context of a country affected by revolution, war and, later, sanctions from other countries. Over time the houses had become rundown and dangerous, particularly in a seismically active country. Areas like Abouzar were officially labelled "deteriorated areas" by the governmental agencies. In the 1990s, the central government and Tehran's municipality undertook several renewal projects; however, the "top-down" approach eventually resulted in failure because of the lack of a social impact assessment, very limited community involvement, and a massive displacement of residents (Etemad, 2013).

Following the Bam earthquake in 2003, which killed 30,000 people in Bam far 


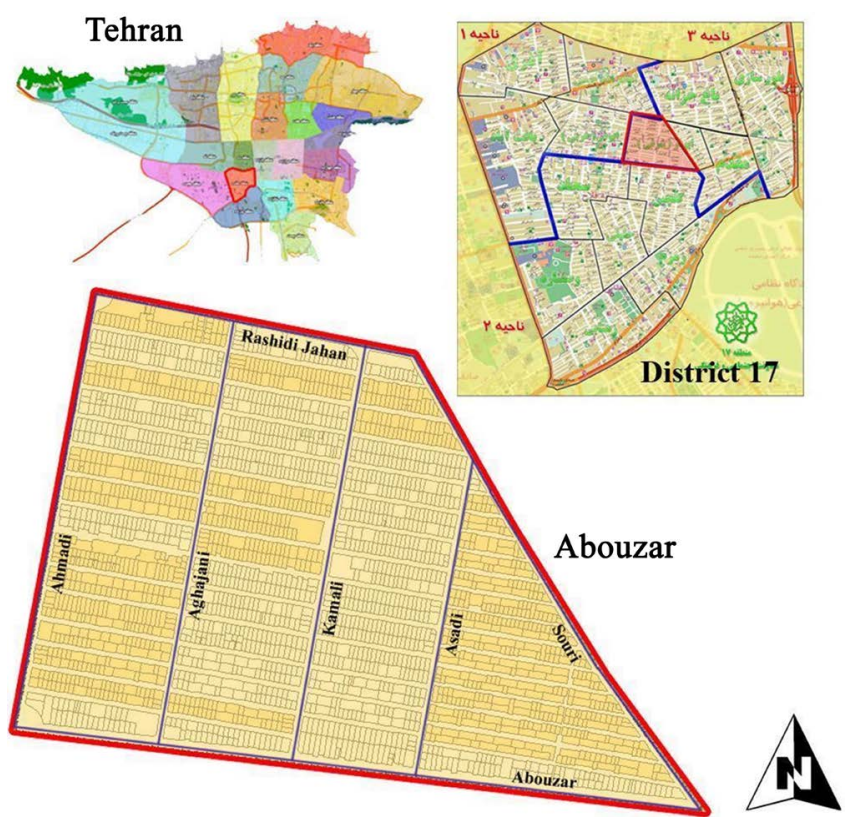

Figure 3. A map of Tehran, Tehran's seventieth district and Abouzar neighborhood (Arad Consulting Engineers, 2016).

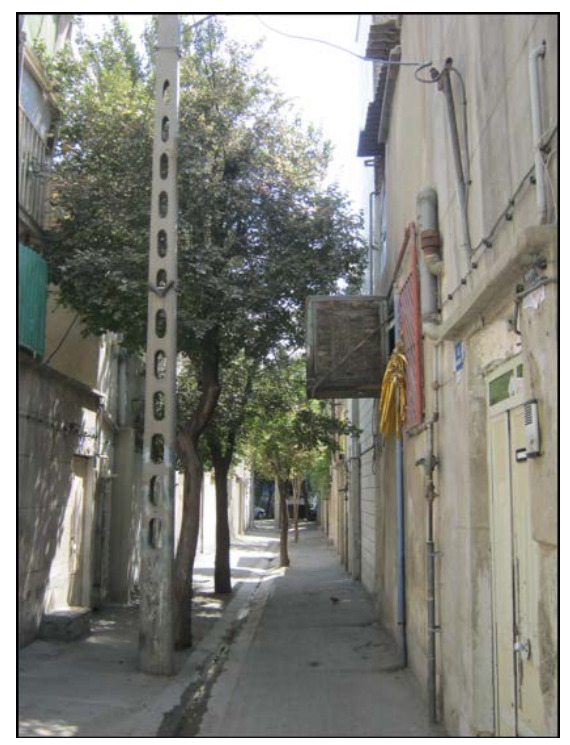

Figure 4. A photo of Ramezani Street in Abouzar in 2010 (Photo by URO project manager, 2010).

away from Tehran (Fallahi, 2007) and the resultant political sensitivity around Tehran as the capital city and home to 2.3 million people, the central government became concerned about earthquake-prone houses in Tehran. Renewal of deteriorated areas became a high priority and a law was passed in 2004 called the "Revitalization and Renewal of Deteriorated Urban Areas". The Tehran city council became the main agency responsible for leading a number of renewal programs in the southern part of the city. The law also required all other relevant government and non-government organizations to work with the council. 
Loans and finance were supposed to be provided by the central government to facilitate the process. The council-led Urban Renewal Organization (URO) which had previously become inactive was revived by the council in 2004 to specifically work on this task. A number of renewal projects were undertaken between 2004 and 2010 but, once again these were considered top-down failures as no one wanted to buy the new apartments. Thus, in 2010, the council and URO initiated a collaborative renewal project bringing together local communities, private developers and homeowners, and the URO/council (and central government institutions indirectly). Abouzar was chosen as a pilot project and began in 2010. After 5 years, around 30 per cent of the neighborhood was rebuilt with further work planned. The Abouzar renewal project was seen by the council as one of the best examples of collaborative governance in Iran.

As in Aranui, New Zealand, Abouzar is home to a range of different ethnicities including Turk, Fars, Kurd, Lor, Afghan (Karaminejad \& Moosavi, 2012). The neighborhood has always had its own elected community board members voted in every four years to represent them at Tehran's city council. Local community board members do not necessarily belong to each and every ethnicity, but they are elected based on trust and their fitness for the job.

While Aranui and Abouzar had some similarities such as having multi-cultural settings, residing low-income families, and physical and social deterioration, they also had some differences. In Abouzar, the houses were privately owned but the owners (in south Tehran) were on low incomes and unable to undertake large-scale renewal themselves. This was the rational for government-led yet collaborative housing renewal projects. In Aranui, the houses were state-owned. Another point of difference is that in Abouzar, private developers were considered key stakeholders and it could be described as a multi-stakeholder setting. In Aranui they were no private "developers", only private contractors, working to the conditions of tenders but with an emphasis on broader neighborhood regeneration. Both areas did, however, have a history of marginalization, poverty, deprivation and "top-down" project management, and more importantly, in both cases, the officials claimed they were implementing collaborative housing renewal. Therefore, these two, provided good examples and platforms for us to investigate collaboration.

\section{Results}

\subsection{Building Trust, Credibility and New Relationships}

As noted above, in both Abouzar and Aranui, government departments identified a need to undertake more collaborative forms of housing renewal in areas marked by a history of top-down projects that had achieved, at best, mixed results for residents. Interviews with officials involved in developing these projects noted high levels of distrust among community members. A local resident from Aranui told HNZC and CCC representatives outright that "We don't trust you. You are government organizations and you have been here before, promised to 
work with us on other things but you haven't. You said something really good and then you left, and it fell over" (Aranui Community Trust Incorporated Society's (ACTIS) manager, 17 Jan 2017).

Against this background, before embarking on a major housing development, officials understood the need to first build credibility and trust as a foundation for new relationships with residents. Interestingly, housing was put aside temporarily while officials developed a better understanding of the area. They started by listening and responding to small, but pressing, concerns over a period of a year in Aranui and 5 months in Abouzar. As one example, after residents of Aranui pointed out the large amount of rubbish around the neighborhood, HNZC and CCC provided funding and support to help community members clean up the area.

We [local people] said'let's clean up the area'... The council dropped the rubbish skips off at different places and the community just brought all the rubbish from their backyards... and filled it and then they [CCC staff] took it away. That was so good. The community really loved it and they got on board with that (ACTIS manager, April 10, 2017).

There were many other examples over the first year where, in Aranui, 24 projects, events and actions were undertaken to respond to issues residents identified (see Table 1). These were a mix of community-led and government-led (but all government-funded) initiatives that achieved early and small wins. The CCC project manager understood how important these small achievements were and noted of this time that:

The early things that we did [were] to prove that we really meant it... by actually demonstrating that we were making sort of physical changes and doing things differently... [For example] one of the early celebrations we had [in Aranui] ... the community decided that the best place was to do it in the middle of the road... Initially people in Aranui wouldn't have thought that was possible, and we demonstrated that that was possible (16 Feb 2017).

The Minister of Parliament representing Aranui also noted:

Gradually [local] people started to put their small yellow sticky notes on the wall and saying all the things [that] they wanted to achieve [in Aranui] and then those things started to happen, and we could say that it was possible (the MP, April 13, 2017).

A key aspect of building trust and improving relationships was on-site presence of the agencies. In both Abouzar and Aranui, community members had asked the agencies involved to be located in the community. Although they were initially reluctant, in both cases, officials did decide to establish a local office with full-time staff. This was considered an early win for the communities, particularly as these offices later became a key meeting place. Importantly, being on-site enabled officials to "see for themselves" rather than "seeing like a state". They were able to simply understand the setting, get to know people, and become familiar with local landmarks and community assets. Co-location in the 
neighborhood enabled different kinds of data based on first-hand observations to be recognized and taken into account. This also reduced the need for communities to convey their concerns in settings and in a language that is not familiar to them. On-site presence, combined with the agencies' responsiveness, not only promoted trust and generated the confidence needed to embark on the larger housing projects.

\subsection{Building a Capable Community}

In some ways, our results indicate that this is where Abouzar and Aranui part company. Though both projects aimed to collaborate on housing renewal, and both began with trust building and on-site presence, the first year in Aranui was devoted to developing a holistic program of work that actually had little to do with "housing". Many projects and events of varying scale were implemented and several of these projects were "community-led". This is quite significant as it raises some critical questions around who or what a community is, and how communities might become able to "partner" with officials in collaborative processes.

The interviews suggested that at the beginning of the Community Renewal project in Aranui, "the" community could be better described as an aggregate of individuals and disparate groups working in the area for their own purposes. There was much capability in evidence, but residents did not necessarily work together as a collective group with the same goals, with recognized leadership. A community development adviser describes Aranui before the renewal project as:

[Aranui] an area with high need... there were a lot of individuals, agencies, support groups and things like that... they weren't working necessarily collectively. They were all doing their own things, for their own purposes in their own ways, and they worked because there was so much of need (Community development advisor, $23 \mathrm{Feb} 2017$ ).

HNZC and CCC representatives saw the lack of community togetherness and leadership as a concern, so they encouraged and supported the community to come together to form a local entity, with local leadership, able to work together towards a collective goal with an identifiable strategy. As the HNZC project manager described it:

One of the things that we [HNZC and CCC] really worked hard at [was], trying to encourage the community to form their own entity, a group that represented them. Because it is all very well having individuals come along and they are a part of the community, but they needed to get to the position that they could act together and speak on behalf of the community rather than just turn up as a person that lives in this street and one person from another street. We wanted to strengthen the community to the extent that they had a voice and they had somebody that represented their voice. So, that was the concept of what ACTIS became. We had to encourage that to happen, we had to support that to happen (30 Jan 2017).

This resulted in the development of the Aranui Community Trust Incorpo- 
rated Society (ACTIS) whose members were both nominated and selected by Aranui locals. Most Board members were already demonstrating leadership in other ways, and they were people who had lived in the area for many years. Consequently, they had an excellent understanding of, and a longstanding commitment to, Aranui. An exception was the chairperson who was not from Aranui, but who was a well-educated lawyer, with good connections to decision-makers, and who had a history of advocating for the community's needs. Over time, ACTIS became more active in the collaboration process, with a defined goal (Aranui development) and a strategy (partnership). Through ACTIS, the community's collective capability became manifest and was multiplied in a way that was significantly different from Aranui before its formation.

Conversely, in Abouzar, this kind of leadership, community and capability-building was missing. Neither the URO nor the council identified or acknowledged the need to enable "the" community to act collectively or become an entity able to act as more of an equal partner. Although the Abouzar community had some existing representatives and leaders, they lacked broader community support and were not able to act collectively as a partner in the collaboration process. Abouzar's collective capability remained latent and potential. The implications of this difference in the two case studies became apparent over time but is neatly encapsulated by the way ACTIS, HNZC and CCC agreed to describe their work as "community renewal" whereas in Abouzar, physical housing redevelopment remained the focus.

\subsection{Building a Mandate}

In both Aranui and Abouzar, the projects had initially been defined as "housing renewal" because it was obvious that there was a "housing problem". This obvious problem had come to the attention of elected members who mobilized their respective agencies to address the housing issues, in a manner consistent with Ansell \& Gash's (2008) notion of a "public" affair and the mandate provided by representative democratic processes. The question is how a mandate is built-and how "public affairs" are identified and defined-through participative democratic processes like those associated with the Aranui case. In Aranui, a large "Needs Analysis Survey" was jointly administered by HNZC, CCC and ACTIS to better understand the community's concerns. The survey included, sixteen focus group discussions (FGDs) with HNZC tenants, private tenants, private homeowners, local Maori and Samoan, primary and high-school students, the police, Department of Correction staff in Aranui, HNZC and CCC staff working in Aranui, community agency representatives (Kelly, 2001). Altogether, 112 individuals took part in interviews and FGDs (Kelly, 2001). The survey was followed by a Youth Forum in which 60 youth participated (Howat, 2001) and then a Park Survey (Figure 5 and Figure 6 illustrate some of the consultation meetings with Aranui community).

The survey results illustrated that the community had three main concerns: 


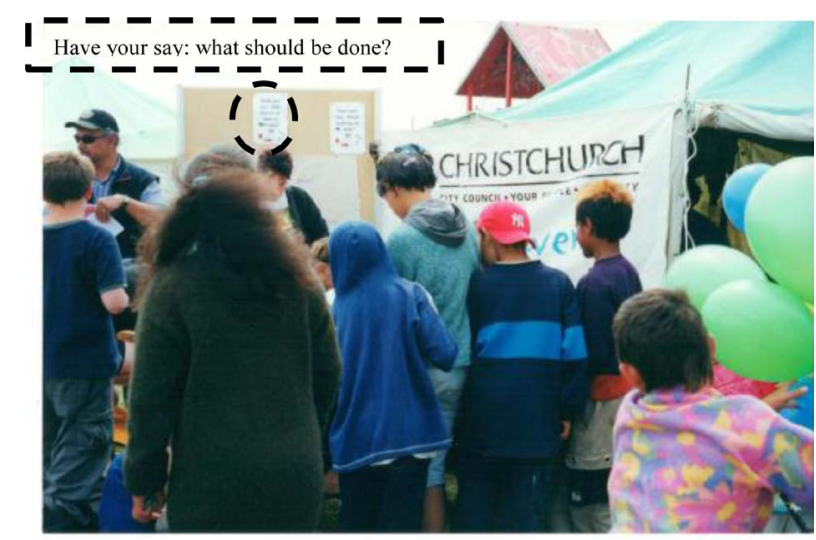

Figure 5. A photo of community consultation in Wainoni Park in Aranui (Photo by CCC Park and Waterways Manager, 2001).

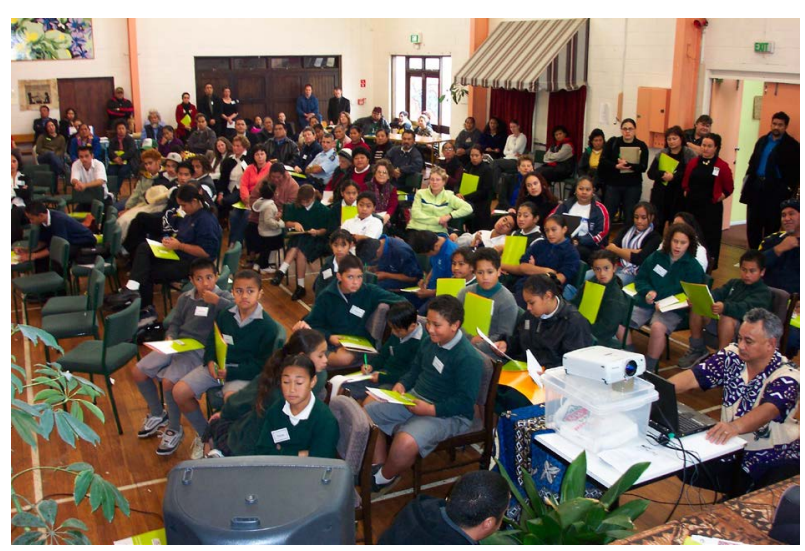

Figure 6. A photo of Fono event as the consultation meeting with the Pacifica people (Photo by CCC Park and Waterways Manager, 2001).

The first related to the physical condition and appearance of state housing and the second highlighted the lack of a proper tenancy management procedure. The third main concern was the lack of safety and facilities in nearby Wainoni Park. HNZC, CCC and ACTIS decided to allocate the main project budget to housing renewal, tenancy management and upgrading Wainoni Park.

In comparison, a large door-to-door needs analysis survey was also conducted in Abouzar and every family in the community was asked about what they saw as the key issues in the neighborhood. This survey highlighted a range of environmental issues, sanitation problems, poor housing and insufficient green spaces such as football fields and playgrounds. These results notwithstanding, the URO and Tehran's council retained their focus on low-cost housing without addressing the broader suite of concerns residents had identified.

The different approaches used in Aranui and Abouzar highlights a problem often encountered in the field: that of identifying and engaging with "the community" versus "stakeholders". There are often well-known representatives of the community, and they can be readily identified as "key stakeholders". Nonetheless, care must be taken because the obvious stakeholders might be partisan 
and represent specific interest(s) rather than the interests of the broader community, as they were in Abouzar. In other cases, it may be that there are no obvious community leaders which make answering the question of who can represent the community more difficult. In such cases, potential or emerging leaders (who are able to represent more than "their" stake) may have to be supported as they were in Aranui. This does, however, raise further questions about representation and mandate.

In Aranui, the first request from ACTIS (in representing the community) to $\mathrm{CCC}$ and HNZC was to sign a formal memorandum of understanding (MoU) articulated as an agreement between three equal partners. The ACTIS chairperson noted that after in inaugural ACTIS meeting, "I sort of said [ to HNZC and CCC representatives], well if we are going to have a partnership, we have to formalize it... we need to negotiate and sign a memorandum of understanding which recognizes the parties" (7 Feb 2017). This was to augment the MoU already in place between HNZC and CCC.

It was agreed that a three-partner memorandum of understanding be drawn up for the Aranui Community Renewal Project. This memorandum would includel respect the full partnership roles of the partners, the Renewals priorities and objectives, the individual roles and responsibilities of the partners, the levels of shared decision-making, and a vision for a self-sufficient community (ACRC, 2001: p. 2).

ACTIS drafted the MoU and included the rights to have a say and be listened to through the whole renewal process. The three parties signed the memorandum and, as one of the ACTIS board members described:

[After the $\mathrm{MoU}$ ] we felt like that we had speaking rights now, not only rights to talk but rights to be heard (10 April 2017).

The MoU also signaled a new phase of community engagement with official support in other ways. HNZC provided a free place for ACTIS to use as an office (Figure 7 shows ACTIS opening day) and CCC provided funds for ACTIS to

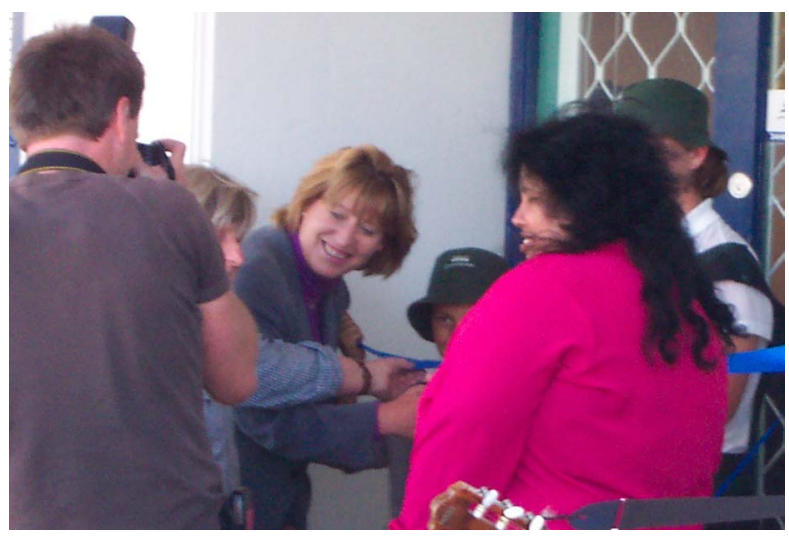

Figure 7. A photo showing the Christchurch East $\mathrm{MP}^{2}$ cutting the ribbon with school pupils on ACTIS opening day (Photo by CCC Park and Waterways Manager, 2001).

${ }^{2}$ Aranui is represented by the MP for Christchurch East. 
employ someone to work full-time for the Trust. The two agencies also provided some funds for ACTIS to spend on things the Trust thought important, some of which are presented in Table 1. In so doing, they improved the community's capacity, confidence and capability to act on its own, but in a way that met established criteria (for Incorporated Trusts and Societies in New Zealand) around reporting, transparency and accountability. The involvement of HNZC, CCC, ACTIS and local residents in decision-making and implementation of certain

Table 1. The table shows a list of projects, events and decisions made in the first 10 month in Aranui, before housing renewal.

\begin{tabular}{|c|c|c|}
\hline When? & What happened? & Who did that? \\
\hline September 2000 & Signing a memorandum of understanding between HNZC and CCC & Housing New Zealand and Christchurch City Council \\
\hline December 2000 & $\begin{array}{l}\text { Establishing the "Community Day" in Wainoni Park as a large fun day for } \\
\text { families }\end{array}$ & $\begin{array}{l}\text { Funded by HNZC and CCC jointly and led by } \\
\text { local residents. }\end{array}$ \\
\hline Late 2000 & $\begin{array}{l}\text { Appointing certain people from organizations to stay in Aranui for the } \\
\text { long-term }\end{array}$ & HNZC and CCC \\
\hline- & Agreement on partnership with the community based on Treaty of Waitangi & HNZC, CCC and Aranui local residents \\
\hline Late 2000 & $\begin{array}{l}\text { Forming a Steering Group (local community's natural leaders were one of } \\
\text { the partners) }\end{array}$ & HNZC, CCC and individuals from the community \\
\hline Feb 2001 & Conducting a survey in the community about the Wainoni park & CCC and HNZC \\
\hline Early 2001 & Skip Day Project & Funded by HNZC and CCC led by local people \\
\hline Early 2001 & Cleaning Back of the Shops & Funded by HNZC and CCC led by local people \\
\hline March 2001 & Holding the large Community Hui/Meeting & Funded by HNZC and CCC led by local people \\
\hline March 2001 & $\begin{array}{l}\text { Establishing Aranui Community Trust Incorporation Society (ACTIS) to } \\
\text { represent Aranui community }\end{array}$ & $\begin{array}{l}\text { Established by Aranui local community but } \\
\text { encouraged and supported by HNZC and CCC }\end{array}$ \\
\hline May 2001 & Basing three full-time tenancy managers in Aranui & HNZC \\
\hline June 2001 & $\begin{array}{l}\text { Establishing a Memorandum of Understanding with ACTIS and forming } \\
\text { "Partnership Group" }\end{array}$ & HNZC, CCC and ACTIS \\
\hline July 2001 & Establishing Aranui Monthly Newsletter & Led by ACTIS, Funded by HNZC and CCC \\
\hline July 2001 & Establishing Saturday Morning Clean-up Project & HNZC, CCC, ACTIS \\
\hline July 2001 & $\begin{array}{l}\text { Establishing the first community-based maintenance contract (Grounds } \\
\text { Maintenance) }\end{array}$ & HNZC and ACTIS \\
\hline August 2001 & Providing an office for ACTIS known as the "Community House" & HNZC \\
\hline August 2001 & ACTIS opening day celebration & HNZC, CCC and ACTIS \\
\hline August 2001 & Conducting Needs Analysis survey & $\begin{array}{l}\text { Funded by HNZC and CCC, led by an } \\
\text { independent researcher }\end{array}$ \\
\hline September 2001 & Conducting Aranui Youth Forum: widespread youth consultation process & Funded by HNZC and CCC, led by CCC \\
\hline September 2001 & Forming Wainoni Park Design Group from local people & CCC and ACTIS \\
\hline December 2001 & Funding ACTIS to employ a full-time on-site co-coordinator for itself & $\mathrm{CCC}$ \\
\hline
\end{tabular}


projects provided an interesting nexus between representative and participative democracy given the range of people involved and the ways in which they were engaged. Working with an elected Member of Parliament also provided a mandate.

\section{Discussion: Building a Strong Foundation for Collaborative Housing Renewal}

The current study highlights the ways in which collaborating with communities on housing projects can be intensely problematic, but also rewarding. Problematic aspects include power imbalances exacerbated by different actors' capacity and capability, status, resources; issues around inclusiveness, impartiality and historical conflict. Given these challenges, our research suggests that the anticipated benefits of a collaborative process are more likely to materialize when the housing project has a strong foundation; indeed, an analogy can usefully be drawn to highlight similarities between the physical construction and the socio-political context within which it sits. To carry the analogy further, whether physical or socio-political, the foundations should be built before the house itself. This signals the importance of groundwork undertaken in advance of more "formal" stages of collaborative approaches to housing renewal. The data presented here highlight three elements that helped build a strong foundation for future housing renewal work: credibility and trusting relationships; a capable community, and a mandate.

Collaborative governance and planning literature often emphasize the work that is undertaken in "formal" settings (such as government offices, meeting rooms at city hall or as written responses to formal, increasingly web-based consultation exercises) with set procedures (minute taking) and following established conventions (chairs, convenors). In comparison, our research suggests decision-makers-both elected and official-should spend at least some time on-site, on building relationships and trust and simply being present before starting formal collaboration on larger projects. On-site presence-combined with responsiveness to a range of small concerns-played an important role in elevating different types of data based on direct observation rather than through standard metrics of census data and other forms of re-presentation. On-site presence also enabled a much broader range of people to participate-or be included-in different, informal, ways. "Inclusion" thus has important qualitative aspects informed by geographical and temporal considerations, such as where (in the neighborhood or in city hall) and at what point of the decision-making cycle are residents are included in housing renewal projects. We emphasize that although it is not uncommon to see the value of small wins highlighted in the literature (Ansell \& Gash, 2008; Saarikoski, 2000; Huxham, 2003), these are often viewed as potentially positive but often optional activities rather than a foundational element of a broader housing project.

Our research also identified building a capable community as foundational. 
Many advocates of collaborative projects accept the importance of organized groups and community representatives as "key stakeholders" (Buanes et al., 2004; Ansell \& Gash, 2008; Rogers et al., 1993). Yet, as English (2000) argues, "the more diffuse the affected stakeholders, and the more long-term the problem horizon, the more difficult it will be to represent stakeholders in collaborative processes" (as cited in Ansell \& Gash, 2008: p. 551). A significant issue is that, often, communities do not have the "organizational infrastructure" needed to effectively represent the community's concerns. Further, while formal stages of collaboration often identify key community stakeholders, the risk is that leaving reconciliation too late sometimes means community representatives can become pitted against each other in a bid to represent "their stake". In contrast, public agencies have well-established organizational structures, defined goals, a culture and history of political decision-making, resources and knowledge, and internal mediation functions and hierarchies that allow them to present a more expert and unified position.

We agree that this is a difficult problem, but not one that is insurmountable if adequate investment is made before more formal, consensus-oriented negotiations begin. A "community" encompasses many individuals, households and groups that, potentially, have many capabilities. Yet they are often diffuse, disparate and fragmented, and do not necessarily work together. Our research suggests that official support may be required to integrate these fragmented capabilities and resources and build a community capable of acting together. The formation of an organized community group (such as ACTIS in Aranui) that initially works towards achieving small wins helps manifest the latent potential-skills are developed and deployed - of apparently disparate stakeholders groups by mobilizing their collective resources and articulating collective concerns as opposed to "their" stake. Although building "a" community does not guarantee that the collaboration will be equal or free of power imbalances, a community that is integrated and has some social infrastructure such as ACTIC was demonstrably better able to act as a partner in more formal processes than a collection of disparate groups and individuals.

This brings us to our final point about the importance of building a mandate. Our traditional notion of representative democracy establishes that elected members have both the right and responsibility to define the nature of "public affairs" (Booher, 2004; Innes \& Booher, 2010; Purdy, 2012; Ansell \& Gash, 2008). They essentially have the formal authority (Purdy, 2012) and elected mandate to define the "ends" whilst the bureaucracy develop alternative "means" of achieving them. Collaboration complicates this simple formula in a number of ways. Purcell's (2009) argument is that neo-liberalization has weakened the state's legitimacy, and collaboration has become an approach to decision-making that restores this lost legitimacy without fundamentally challenging entrenched market logics. From a practical perspective, it has been noted that participants in formal collaborative projects will, justifiably, expect their views to be taken into account 
which presents potential issues for official decision-makers who might hold contrasting views. Finally, scholarship interrogating the ontological politics involved in making issues public (Stivers, 2009; Whatmore \& Landström, 2011; Dantec \& DiSalvo, 2013; Vallance et al., 2017) also raises interesting questions about the types of legitimacy conferred through diverse forms of active participation. These may involve anything from web-based instances of direct democracy (the new click-ocracy) to the development of temporary "pop up" parks. In short, there are various tensions between participative and representative democracy that may shape collaboration.

Our research indicates a number of ways in which these tensions may be alleviated by attending to the foundations upon which formal collaboration can later proceed. First, our cases highlighted the ways in which elected members and officials came to understand the nature of "the problem". Rather than seeing like a state (Taylor, 1998) using standard socio-demographic metrics and other representations, they came to see for themselves. While elected members' visits were infrequent, officials came... and stayed. Their attitude was also important. In theory, public agencies often start from a position of assumed knowledge about public issues and have often already, to some extent, defined the problem. Our study suggests that starting with an attitude of assumed ignorance about community issues/public affairs may actually be just as helpful. In Aranui, the co-operated needs analysis helped shape the subsequent program of work. This laid the foundation for the more formal stage of collaboration, signaled by the signing of the MoU which then endowed the process with a sense of legitimacy among all parties.

Figure 8 illustrates the framework and indicators that we have developed for a foundational phase or pre-collaboration phase in collaborative governance and planning.

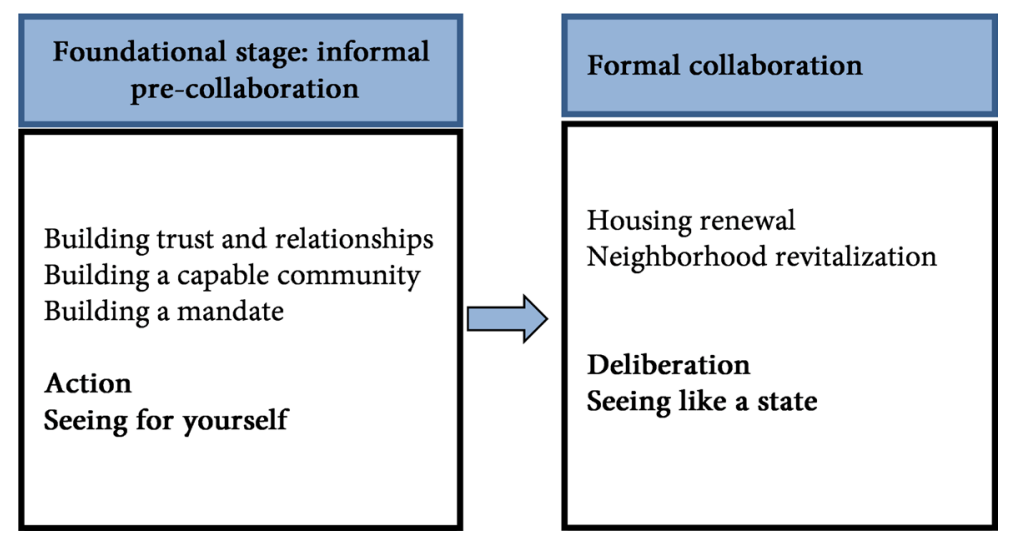

Figure 8. Informal "pre-collaboration" and formal collaboration in the context of collaborative governance and collaborative planning.

\section{Conclusion}

The two case studies detailed in this research contribute to our understanding of 
collaboration by indicating the need to extend and expand our conceptualization to more fully attend to the informal-we would argue foundational-stage of housing renewal projects or pre-collaboration. Although well-established criteria such as balancing power, being inclusive, achieving consensus and agreement (e.g. Healey, 1997; Innes \& Booher, 2010; Dryzek, 1994) are appealing, we argue that they are difficult to achieve within the confines of "a formal process", particularly when working with communities as a type of stakeholder. Our results suggest that formal stages of collaboration should be deferred until adequate levels of credibility, trust, relationships, community capability, and an appropriate mandate have been built.

In terms of theory, we conclude that our conceptualization of collaboration needs significantly more nuance, not only in terms of the types of collaboration that take place, but also in terms of relationships between foundational and formal phases. The implications of this lie in recognizing the co-constitutional nature of what we have come to see as somewhat distinct though obviously related phases, and in understanding that many of the criticisms directed at formal collaboration may be attributed to insufficient groundwork. In practical terms, this means allowing for adequate time and resource budgets, and in employing officials who have not just technical aptitude but an appropriate attitude of open-mindedness.

This signals a further contribution arising from our research pertaining to the uneasy relationship between participative and representative democracy, particularly in settings where the very legitimacy of the state has been compromised. Perhaps not surprisingly, there has been a strong thread of scholarship emerging in political theory (Parvin, 2020) and in applied research in places where this loss of legitimacy is readily apparent (Modise, 2017; Balderacchi, 2016), yet a coalescence of these themes within the collaborative urban planning and governance literature from "healthy" Western democracies is relatively weak. In positing a foundational stage of collaboration, we have identified points at which some rapprochement may be achieved: deeper involvement on-site of elected members and officials and the co-design and even co-operation of the issue/agenda and means of implementation. In short, we highlight overall that collaborative housing projects cannot be viewed primarily as technical or engineering achievements, rather, they are socio-political aspirations that require a strong foundation if the broader intent of renewal is to be achieved.

\section{Acknowledgements}

This work was supported and funded by Lincoln University Postgrad Commission and National Science Challenge Building Better Homes, Towns and Cities, New Zealand.

\section{Conflicts of Interest}

The authors declare no conflicts of interest regarding the publication of this paper. 


\section{References}

ACRC (2001). Working through the Agenda. Minutes of Aranui Community Renewal Committee 19 June 2001. Christchurch.

Agger, A., \& Lögren, K. (2008). Democratic Assessment of Collaborative Planning processes. Planning Theory, 7, 145-164. https://doi.org/10.1177/1473095208090432

Andranovich, G. (1995). Achieving Consensus in Public Decision Making: Applying Interest-Based Problem Solving to the Challenges of Intergovernmental Collaboration. The Journal of Applied Behavioral Science, 31, 429-445. https://doi.org/10.1177/0021886395314003

Ansell, C., \& Gash, A. (2008). Collaborative Governance in Theory and Practice. Journal of Public Administration Research and Theory, 18, 543-571. https://doi.org/10.1093/jopart/mum032

Babbie, E. R. (2016). The Practice of Social Research (14th ed.). Boston: Cengage Learning.

Balderacchi, C. (2016). Problems and Contradictions of Participatory Democracy: Lessons from Latin America. Contemporary Politics, 22, 164-177. https://doi.org/10.1080/13569775.2016.1153282

Booher, D. E. (2004). Collaborative Governance Practices and Democracy. National Civic Review, 93, 32-46. https://doi.org/10.1002/ncr.69

Bortel, G., \& Gruis, V. (2019). Innovative Arrangements between Public and Private Actors in Affordable Housing Provision: Examples from Austria, England and Italy. Urban Science, 3, 52-56. https://doi.org/10.3390/urbansci3020052

Boyd, F. (2011). The Evolution of a State-Funded Subdivision-A Case study: Aranui and Wainoni. Master Thesis, Lincoln: Lincoln University. https://researcharchive.lincoln.ac.nz/handle/10182/4398

Brisbois, M. C. (2015). Natural Resource Industries and the State in Collaborative Approaches to Water Governance: A Power-Based Analysis. Doctoral Thesis, Canada: University of Waterloo. https://uwspace.uwaterloo.ca/handle/10012/9569

Buanes, A., Jentoft, S., Karlsen, G. R., Maurstad, A., \& Søreng, S. (2004). In Whose Interest? An Exploratory Analysis of Stakeholders in Norwegian Coastal Zone Planning. Ocean \& Coastal Management, 47, 207-223. https://doi.org/10.1016/j.ocecoaman.2004.04.006

Cowie, P. (2017). Performing Planning: Understanding Community Participation in Planning through Theatre. Town Planning Review, 88, 401-422.

https://doi.org/10.3828/tpr.2017.26

Creswell, J. W., \& Creswell, J. D. (2017). Research Design: Qualitative, Quantitative, and Mixed Methods Approaches (2nd ed.). California: Sage Publications.

Czischke, D., Carriou, C., \& Lang, R. (2020). Collaborative Housing in Europe: Conceptualizing the Field. Housing Theory and Society, 37, 1-9.

https://doi.org/10.1080/14036096.2020.1703611

Dantec, C. A. L., \& DiSalvo, C. (2013). Infrastructuring and the Formation of Publics in Participatory Design. Social Studies of Science, 43, 241-264.

https://doi.org/10.1177/0306312712471581

Dryzek, J. S. (1994). Discursive Democracy: Politics, Policy, and Political Science. Cambridge, England: Cambridge University Press.

Emerson, K., \& Nabatchi, T. (2015). Evaluating the Productivity of Collaborative Governance Regimes: A Performance Matrix. Public Performance \& Management Review, 
38, 717-747. https://doi.org/10.1080/15309576.2015.1031016

Emerson, K., Nabatchi, T., \& Balogh, S. (2012). An Integrative Framework for Collaborative Governance. Journal of Public Administration Research and Theory, 22, 1-29. https://doi.org/10.1093/jopart/mur011

English, M. R. (2000). Who Are the Stakeholders in Environmental Risk Decisions-How Should They Be Involved. Risk, 11, 243-254.

Etemad, G. (2013). Evaluating Navvab Project and the Consequences. Tehran, Iran: Maani.

Fallahi, A. (2007). Lessons Learned from the Housing Reconstruction Following the Bam Earthquake in Iran. The Australian Journal of Emergency Management, 22, 26-35.

Flyvbjerg, B. (2001). Making Social Science Matter: Why Social Inquiry Fails and How It Can Succeed Again. Cambridge, England: Cambridge University Press. https://doi.org/10.1017/CBO9780511810503

Forester, J. (1999). The Deliberative Practitioner: Encouraging Participatory Planning Processes. Cambridge, MA: The MIT Press.

Futrell, R. (2003). Technical Adversarialism and Participatory Collaboration in the US Chemical Weapons Disposal Program. Science, Technology, \& Human Values, 28, 451-482. https://doi.org/10.1177/0162243903252762

Gray, B. (1989). Collaborating: Finding Common Ground for Multiparty Problems. San Francisco, CA: Jossy-Bass.

Gunton, T. I., \& Day, J. C. (2003). The Theory and Practice of Collaborative Planning in Resource and Environmental Management. Environments, 31, 5-20.

Habermas, J. (1984). The Theory of Communicative Action. Boston, MA: Beacon press.

Healey, P. (1997). Collaborative Planning: Shaping Places in Fragmented Societies. London, England: Macmillan Press Ltd. https://doi.org/10.1007/978-1-349-25538-2

Healey, P. (2010). Making Better Places: The Planning Project in the Twenty-First Century. London: Macmillan International Higher Education. https://doi.org/10.1007/978-1-137-01379-8

Hillier, J. (2003). Agon'izing over Consensus: Why Habermasian Ideals Cannot Be Real. Planning Theory, 2, 37-59. https://doi.org/10.1177/1473095203002001005

HNZC (2000). Background Information for Preliminary Scoping Workshop: Housing New Zealand Corporation. Housing New Zealand Corporation.

Howat, K. (2001). Aranui Youth Forum. Aranui Community Trust Incorporated Society.

Huxham, C. (2003). Theorizing Collaboration Practice. Public Management Review, 5, 401-423. https://doi.org/10.1080/1471903032000146964

Innes, J. E., \& Booher, D. E. (1999). Consensus Building and Complex Adaptive Systems: A Framework for Evaluating Collaborative Planning. Journal of the American planning association, 65, 412-423. https://doi.org/10.1080/01944369908976071

Innes, J. E., \& Booher, D. E. (2003). Collaborative Policymaking: Governance through Dialogue. In Deliberative Policy Analysis: Understanding Governance in the Network Society (pp. 33-59). Cambridge, UK: Cambridge University Press. https://doi.org/10.1017/CBO9780511490934.003

Innes, J. E., \& Booher, D. E. (2010). Planning with Complexity: An Introduction to Collaborative Rationality for Public Policy. Abingdon, Oxon; New York, NY: Routledge. https://doi.org/10.4324/9780203864302

Jiménez, A. C. (2014). The Right to Infrastructure: A Prototype for Open Source Urban- 
ism. Environment and Planning D: Society and Space, 32, 342-362.

https://doi.org/10.1068/d13077p

Kapucu, N., \& Garayev, V. (2011). Collaborative Decision-Making in Emergency and Disaster Management. International Journal of Public Administration, 34, 366-375. https://doi.org/10.1080/01900692.2011.561477

Karaminejad, Z. \& Moosavi, J. (2012). Participatory Project of Urban Renewal of Distressed Areas in Tehran City (Case Study: Moghadam Neighbourhood). Arad Consulting Engineers.

Kelly, S. (2001). Community Needs Analysis towards Aranui Community Renewal.

Koontz, T. M., \& Newig, J. (2014). From Planning to Implementation: Top-Down and Bottom-Up Approaches for Collaborative Watershed Management. Policy Studies Journal, 42, 416-442. https://doi.org/10.1111/psj.12067

Lane, M. B. (2005). Public Participation in Planning: An Intellectual History. Australian Geographer, 36, 283-299. https://doi.org/10.1080/00049180500325694

Laurian, L., \& Shaw, M. M. (2008). Evaluation of Public Participation: The Practices of Certified Planners. Journal of Planning Education and Research, 28, 293-309. https://doi.org/10.1177/0739456X08326532

Leach, W. D. (2006). Collaborative Public Management and Democracy: Evidence from Western Watershed Partnerships. Public Administration Review, 66, 100-110. https://doi.org/10.1111/j.1540-6210.2006.00670.x

Lewandowsky, S., Mann, M. E., Brown, N. J., \& Friedman, H. (2016). Science and the Public: Debate, Denial, and Skepticism. Journal of Social and Political Psychology, 4, 537-553. https://doi.org/10.5964/jspp.v4i2.604

Margerum, R. D. (2002). Collaborative Planning: Building Consensus and Building a Distinct Model for Practice. Journal of Planning Education and Research, 21, 237-253. https://doi.org/10.1177/0739456X0202100302

McCarthy, J. (2016). Partnership, Collaborative Planning and Urban Regeneration. London: Routledge. https://doi.org/10.4324/9781315599588

Memon, A., Duncan, R., \& Spicer, A. (2012). The Hurunui Waiau Zone Implementation Programme as a Collaborative Planning Process: A Preliminary Review. Christchurch, New Zealand: Environment Canterbury.

Modise, L. J. (2017). The Notion of Participatory Democracy in Relation to Local Ward Committees: The Distribution of Power. In die Skriflig, 51, 1-8. https://doi.org/10.4102/ids.v51i1.2248

Montgomery, R. (2016). State Intervention in a Post-War Suburban Public Housing Project in Christchurch, New Zealand. Articulo-Journal of Urban Research, 13, 1-13.

Mouffe, C. (2000). The Democratic Paradox. London, England: Verso.

Neuman, L. W. (2011). Social Research Methods: Qualitative and Quantitative Approaches (7th ed.). Essex, England: Pearson Education Limited.

O’Flynn, J., \& Wanna, J. (2008). Collaborative Governance: A New Era of Public Policy in Australia?Canberra, Australia: ANU E Press. https://doi.org/10.26530/OAPEN_458884

O’Leary, R., \& Bingham, L. B. (2007). Conclusion: Conflict and Collaboration in Networks. International Public Management Journal, 10, 103-109. https://doi.org/10.1080/10967490601185799

Papadopoulos, Y. (2012) The Democratic Quality of Collaborative Governance. In D. Levi-Faur (Ed.), The Oxford Handbook of Governance (pp. 512-526). Oxford: Oxford 
University Press. https://doi.org/10.1093/oxfordhb/9780199560530.013.0036

Parvin, P. (2020). The Participatory Paradox: An Egalitarian Critique of Participatory Democracy. Journal of Representative Democracy, 56, 1-23.

https://doi.org/10.1080/00344893.2020.1823461

Purbani, K. (2017). Collaborative Planning for City Development. A Perspective from a City Planner. Scientific Review Engineering and Environmental Sciences, 26, 136-147. https://doi.org/10.22630/PNIKS.2017.26.1.12

Purcell, M. (2009). Resisting Neoliberalization: Communicative Planning or Counter-Hegemonic Movements? Planning Theory, 8, 140-165.

https://doi.org/10.1177/1473095209102232

Purdy, J. M. (2012). A Framework for Assessing Power in Collaborative Governance Processes. Public Administration Review, 72, 409-417. https://doi.org/10.1111/j.1540-6210.2011.02525.x

Rasoolimanesh, M., Jaafar, M., \& Badarulzaman, N. (2013). Urban Planning and Management System in Iran: A Review and Assessment. Middle-East Journal of Scientific Research, 18, 220-229.

Rogers, T., Howard-Pitney, B., Feighery, E. C., Altman, D. G., Endres, J. M., \& Roeseler, A. G. (1993). Characteristics and Participant Perceptions of Tobacco Control Coalitions in California. Health Education Research, 8, 345-357.

https://doi.org/10.1093/her/8.3.345

Roy, P. (2015). Collaborative Planning-A Neoliberal Strategy? A Study of the Atlanta BeltLine. Cities, 43, 59-68. https://doi.org/10.1016/j.cities.2014.11.010

Saarikoski, H. (2000). Environmental Impact Assessment (EIA) as Collaborative Learning Process. Environmental Impact Assessment Review, 20, 681-700.

https://doi.org/10.1016/S0195-9255(00)00059-7

Schrader, B. (2005). We Call It Home: A History of State Housing in New Zealand. Auckland, New Zealand: Reed.

Statistics New Zealand(2001). http://nzdotstat.stats.govt.nz.

Stivers, C. (2009). The Ontology of Public Space: Grounding Governance in Social Reality. American Behavioural Scientist, 52, 1095-1108. https://doi.org/10.1177/0002764208327677

Szemzö, H., Gerőházi, É., Droste, C., \& Soetanto, D. (2019). Towards a Collaborative Housing Initiative: The Role of Local Authorities. Built Environment, 45, 398-415. https://doi.org/10.2148/benv.45.3.398

Taylor, N. (1998). Urban Planning Theory since 1945. London, England: Sage Publications.

Vallance, S., Dupuis, A., Thorns, D., \& Edwards, S. (2017). Temporary Use and the Onto-Politics of "Public" Space. Cities, 70, 83-90.

https://doi.org/10.1016/j.cities.2017.06.023

Warner, J. F. (2006). More Sustainable Participation? Multi-Stakeholder Platforms for Integrated catchment Management. Water Resources Development, 22, 15-35.

https://doi.org/10.1080/07900620500404992

Weber, E. P. (2003). Bringing Society Back in: Grassroots Ecosystem Management, Accountability, and Sustainable Communities. Cambridge, MA: MIT Press. https://doi.org/10.7551/mitpress/1672.001.0001

Whatmore, S. J., \& Landström, C. (2011). Flood Apprentices: An Exercise in Making 
Things Public. Economy and Society, 40, 582-610.

https://doi.org/10.1080/03085147.2011.602540

Yin, R. K. (2009). Case Study Research: Design and Methods (4th ed.). Los Angeles, CA: Sage Publications. 